\title{
Repeatability of subjective grading in fur animals I. Grading of live foxes (Vulpes vulpes)
}

\author{
HILKKA KeNTTÄMIES and HARRI KÄYHKÖ
}

\begin{abstract}
KENTTÄMIES, H. \& KÄYHKÖ, H. 1992. Repeatability of subjective grading in fur animals. I. Grading of live foxes (Vulpes vulpes). Agric. Sci. Finl. 1: 303-307. (Univ. Helsinki, Dept. Anim. Breed., SF-00710 Helsinki, Finland and Turkis-Sampo, SF83900 Juuka, Finland.)

Repeatabilities of subjective grading were studied for colour and body size in silver foxes, and for general appearance in various colour types of the fox. Statistically significant differences between scoring times were found for each trait. However, the judge factor had the greatest effect on scores for colour and body size in silver foxes. There were differences between the mean scores in general appearance given for the various colour types. Colour tended to be easier to judge than body size or general appearance. The coefficients of repeatability were 0.74 for colour, 0.55 for body size and 0.57 for general appearance. The repeatabilities among the various judges were $0.68-0.82$ for colour and $0.51-0.59$ for body size. Among the various colour types the "silver types" seemed to be easier to judge than the "golden types". The repeatabilities were 0.57 to 0.59 vs. 0.50 to 0.55 for general appearance.
\end{abstract}

Key words: silver fox, body size, colour, repeated grading

\section{Introduction}

Body size and fur characteristics of live fur animals are usually subjectively graded. A lack of objective methods to estimate colour and fur quality in farm conditions has led to subjective judging. In addition, scoring may be quickly conducted. The high reliability of evaluation for body size and fur characteristics is important for the selection of the breeding animals. However, grading may be affected by species and colour types, skill of the judge, circumstances of the farm and variations in lighting conditions (JONSSON 1970, JEŻEWSKA and MACIEJOWSKI 1982).

In order to study the accuracy of evaluation, the coefficient of repeatability can be estimated from the repeated scorings. Repeated judging of exterior traits in fur bearing animals has been previously studied mainly in minks (JoNSSON 1970, MACIEJOWSKI and SŁAWOŃ 1973, REITEN 1977, JEŻEWSKA ET AL. 1981, JeŻEWSKA and MACIEJOWSKI 1982, Børsting and Clausen 1986, KentTÄmies and VILVA 1988). In ADDITION, JeŻEWSKA and MACIEJOWSKI (1982) performed repeatability studies in silver foxes and blue foxes.

The purpose of the present investigation was to study the repeatability of grading scores for body size, colour and general appearance in foxes, and the factors affecting the scores.

\section{Material and methods}

Repeated grading in live foxes was studied in a private farm Turkis-Sampo. In two samples the an- 
imals were graded three times by each judge. In October 1986 five persons judged the colour and body size of 248 live purebred silver foxes (Sample 1). The animals were males and females in a 1:1 ratio. In December 1989 one person judged the general appearance of 2063 foxes (Sample 2). The animals were males of several colour types of fox. In the both samples the animals were graded in individual cages on a scale from 1 to 5 (Table 1). An automatic recorder was utilized in the recording of the scores.

The materials were edited and analysed using the statistical program WSYS (VILVA 1987). Factors affecting the traits were studied by the analysis of variance using models, where all the effects were considered fixed. In Sample 1 the following model was applied:

Model 1:

$\mathrm{Y}_{\mathrm{ijkl}}=\mu+\mathrm{a}_{\mathrm{i}}+\mathrm{b}_{\mathrm{j}}+\mathrm{c}_{\mathrm{k}}+\mathrm{e}_{\mathrm{ijkl}}$ where $\mathrm{Y}_{\mathrm{ijk \textrm {k }}}=$ body size or colour of the lth scoring $\mu=$ general mean

$a_{i}=$ effect of the ith judge; $i=1-5$

$b_{j}=$ effect of the $j$ th time of grading; $j=1-3$

$c_{k}=$ effect of the kth sex; $k=1,2$

$\mathrm{e}_{\mathrm{i} \mathrm{jkl}}=$ random error

In Sample 2 the Y-variable was general appearance and the model included colour type of foxes and time of grading.

The repeatability coefficients of the traits were analysed using random and mixed models. In the completely random model the effects of the judges were ignored, and the data were analysed using the following random model:

Model 2:

$\mathrm{Y}_{\mathrm{ij}}=\mu+\mathrm{d}_{\mathrm{i}}+\mathrm{e}_{\mathrm{ij}}$ where $\mathrm{d}_{\mathrm{i}}=$ effect of the $i$ th animal with all other factors as described in Model 1.

Model 2 was also used in analysing repeatabilities separately by judges (Sample 1) and colour types (Sample 2). In addition, for Sample 1 the effects of animal were analysed separately by males and females.

In order to eliminate the effects of the judge on the coefficients in Sample 1, the following hierarchic model was used:

Model 3:

$\mathrm{Y}_{\mathrm{ijk}}=\mu+\mathrm{a}_{\mathrm{i}}+\mathrm{d}_{\mathrm{ij}}+\mathrm{e}_{\mathrm{ijk}}$

where $\mathrm{d}_{\mathrm{ij}}=$ random effect of the $j$ th animal within $i$ th judge with all other effects as described in Model 1.

In Sample 2 the Y-variable was general appearance and the model included colour type of foxes and animal.

\section{Results and discussion}

\section{Means and standard deviations}

The data consisted of a total of 3720 observations in Sample 1, and of 6189 ones in Sample 2. Slightly higher scores were given for general appearance than for colour and body size. There existed plenty of variation in the traits. Standard deviations for general appearance tended to be lower than for the other traits (Table 2). Similar means were found for the general appearance of different colour types. However, larger variation appeared for silver fox type and the cross foxes as compared to those with a gene for platina or arctic marble colour type.

Table 1. Number $(\mathrm{N})$ and colour type of foxes and scoring of the traits graded in Samples 1 and 2.

\begin{tabular}{clllll}
\hline Sample & N & Colour type & Trait & Scores & $\begin{array}{l}\text { Number of } \\
\text { judges }\end{array}$ \\
\hline 1 & 248 & Silver fox & Body size & 1 (small)-5 (large) & 5 \\
1 & 248 & Silver fox & Colour & 1 (dark)-5 (light) & 5 \\
2 & 2063 & Various & General appearance & 1(poor)-5 (excellent) & 1 \\
\hline
\end{tabular}


Table 2. Total number of observations (N), means and standard deviations (SD) for the traits graded in Samples 1 and 2.

\begin{tabular}{llll}
\hline Trait & $\mathrm{N}$ & Mean & $\mathrm{SD}$ \\
\hline Body size & 3720 & 3.17 & 0.76 \\
Colour & 3720 & 3.01 & 0.83 \\
General appearance & 6189 & 3.43 & 0.66 \\
\hline
\end{tabular}

\section{Factors affecting the traits}

In Sample 1 there were statistically significant differences between judges and scoring times for colour and body size, as well as differences between males and females for colour (Table 3). The judge had the greatest effect on the scores. There was a tendency for graders to perceive body size as getting larger on subsequent gradings.

In Sample 2, statistically significant differences between colour types and times of grading were found in scores for general appearance (Table 4). Lower scores for general appearance were given to the golden cross foxes and the silver cross foxes as compared with the other colour types. The scale of grading tended to get stricter on the third time of scoring.

\section{Repeatability of evaluation}

The repeatabilities of grading scores analysed within animals were 0.30 for colour, 0.40 for body size and 0.57 for general appearance (Table 5). A slightly higher repeatability coefficient was found for colour of females (0.69) as compared with males (0.66), in line with REITEN (1977). In previous studies with live minks and silver foxes, colour has appeared to be easier to judge as compared with the fur quality traits and total evaluation (JONSSON 1970, ReITEN 1977, JEŻEWSKA and MACIEJOWSKI 1982). The fairly low repeatabilities for body size in the present study could be due to the fact that the animals were in cages during the grading.

Average repeatabilities after eliminating the effects of the judge on scores were 0.74 for colour and 0.55 for body size (Table 5). Differences
Table 3. Effect of the judge, time for scoring and sex of an animal on scores for body size and colour in Sample 1.

\begin{tabular}{|c|c|c|c|}
\hline \multirow[t]{2}{*}{ Factor } & \multirow[t]{2}{*}{$\mathrm{N}$} & \multicolumn{2}{|c|}{ LS-means } \\
\hline & & Body size & Colour \\
\hline \multicolumn{4}{|l|}{ Judge } \\
\hline 1 & 744 & 3.11 & 3.12 \\
\hline 2 & 744 & 2.91 & 2.99 \\
\hline 3 & 744 & 2.91 & 2.78 \\
\hline 4 & 744 & 3.48 & 2.98 \\
\hline 5 & 744 & 3.45 & 3.17 \\
\hline F-statistics & & $* * *$ & $* * *$ \\
\hline \multicolumn{4}{|c|}{ Time of scoring } \\
\hline 1 & 1240 & 3.13 & 3.05 \\
\hline 2 & 1240 & 3.17 & 2.97 \\
\hline 3 & 1240 & 3.21 & 3.00 \\
\hline F-statistics & & $*$ & $*$ \\
\hline \multicolumn{4}{|c|}{ Sex of animal } \\
\hline Males & 1860 & 3.15 & 3.04 \\
\hline Females & 1860 & 3.20 & 2.97 \\
\hline F-statistics & & NS & ** \\
\hline
\end{tabular}

Table 4. Effect of the colour type of an animal and time for scoring on scores for general appearance in Sample 2.

\begin{tabular}{lrr}
\hline \multirow{2}{*}{ Factor } & $\mathrm{N}$ & \multicolumn{1}{c}{ LS-mean } \\
\cline { 3 - 3 } & & General appearance \\
\hline Colour type & & \\
Silver fox & 5208 & 3.45 \\
Gold fox & 372 & 3.35 \\
Gold/silver cross fox & 207 & 3.15 \\
Platinum, arctic marble & 336 & 3.43 \\
Platinum/sun glow gold/ & & \\
$\quad$ cross fox & 60 & 3.50 \\
F-statistics & & $* * *$ \\
& & \\
Time of scoring & & \\
1 & 2061 & 3.44 \\
2 & 2061 & 3.44 \\
3 & 2061 & $* * *$ \\
F-statistics & & \\
\hline
\end{tabular}

$* * *(\mathrm{P}<0.001)$

between judges in their ability to repeat their grading scores were obvious. The repeatability coefficients among the various judges were $0.68-0.82$ for 
Table 5 . The repeatability coefficients \pm the standard errors for the traits studied in Samples 1 and 2.

\begin{tabular}{lccc}
\hline \multirow{2}{*}{ Trait } & Sample & \multicolumn{2}{c}{ Repeatabilities \pm Standard errors } \\
\cline { 2 - 4 } & & Within animal & $\begin{array}{c}\text { Within judge/ } \\
\text { colour type } \\
\text { and animal }\end{array}$ \\
\hline Body size & 1 & $0.40 \pm 0.03$ & $0.55 \pm 0.02$ \\
Colour & 1 & $0.30 \pm 0.02$ & $0.74 \pm 0.01$ \\
General appearance & 2 & $0.57 \pm 0.01$ & $0.57 \pm 0.01$ \\
\hline
\end{tabular}

colour and $0.51-0.59$ for body size (Table 6). One of the judges graded both traits more reliably than the others. Likewise in previous studies with live minks, silver foxes and blue foxes, differences between various judges have been found in repeatability of grading for colour, fur quality and total evaluation (JoNSSON 1970, JEZEWSKA and MACIEJOWSKI 1982).

Among the different colour types of the present study the "'silver types"' seemed to be easier to judge than the "'golden types". The coefficients of repeatability were 0.57 to 0.59 vs 0.50 to 0.55 (Table 7).
Table 6 . The repeatability coefficients \pm the standard errors for body size and colour of silver foxes graded by various judges in Sample 1.

\begin{tabular}{lcc}
\hline Judge & \multicolumn{2}{c}{ Repeatabilities \pm Standard errors } \\
\cline { 2 - 3 } & Body size & Colour \\
\hline 1 & $0.51 \pm 0.04$ & $0.72 \pm 0.03$ \\
2 & $0.59 \pm 0.03$ & $0.68 \pm 0.03$ \\
3 & $0.51 \pm 0.04$ & $0.68 \pm 0.03$ \\
4 & $0.51 \pm 0.04$ & $0.78 \pm 0.02$ \\
5 & $0.59 \pm 0.03$ & $0.82 \pm 0.02$ \\
\hline
\end{tabular}

Table 7 . The repeatability coefficients \pm the standard errors for general appearance in different colour types of fox in Sample 2 .

Colour type

Repeatabilities \pm Standard errors General appearance

$\begin{array}{ll}\text { Silver fox } & 0.57 \pm 0.01 \\ \text { Gold fox } & 0.55 \pm 0.05 \\ \text { Gold/silver cross fox } & 0.50 \pm 0.07 \\ \text { Platinum, arctic marble } & 0.59 \pm 0.05 \\ \text { Platinum/sun glow gold/cross fox } & 0.54 \pm 0.13\end{array}$

\section{References}

Børsting, E. \& Clausen, J. 1986. Anvendelse av livdyrvurdering i minkavel. NJF Utredning Rapport no. 27. 5 p.

JeżewSKa, G., Maciejowski, J. \& Sławoń, J. 1981. Variability and repeatability of estimates of exterior features of minks of the Standard variety. Zesz. Problemowe Postepow Nauk Roln. 259: 121-128.

JeŻEWSKA, G. \& MACIEJOWSKI, J. 1982. Repeatability of exterior trait estimations in different species of fur animals. 33rd EAAP, Leningrad. 16.-19.9.1982. 9 p.

JoNSSON, M.B. 1970. Variasjonsårsaker for noen produksjonsegenskaper hos mink. Meld. Norg. Landbr.høgsk. 50 , no. 6, 47 p.

Kenttămies, H. \& Vilva, V. 1988. Phenotypic and genetic parameters for body size and fur characteristics in mink. Acta Agric. Scand. 38: 243-252.

MACIEJOWSKI, J. \& Sł.AwoŃ, J. 1973. Subjectivity of licence estimations of Standard minks as the source of mistakes in breeding. Prace i Materialy Zootechniczne 4 (1973): 69-82.
REITEN, J. 1977. Korrelasjoner mellom størrelse og pelsegenskaper hos mørk mink. Meld. Norg. Landbr.høgsk. 56 , no. 14,15 p.

VILVA, V. 1987. Statistical microcomputer program WSYS Univ. Helsinki, Dept. Anim. Breed.

Manuscript received November 1991

\section{Hilkka Kenttämies}

University of Helsinki

Department of Animal Breeding

SF-00710 Helsinki, Finland

Harri Käyhkö

Turkis-Sampo

83900 Juuka, Finland

Present adress:

Lähdetie 2 B 5

SF-80710 Lehmo, Finland 


\title{
SELOSTUS
}

\section{Turkiseläinten subjektiivisen arvostelun toistettavuus I. Elävien kettujen ( Vulpes vulpes) arvostelu}

\author{
HILKKA KeNTTÄMIES ja HARRI KÄYHKÖ \\ Helsingin yliopisto ja Turkis-Sampo
}

Subjektiivisen arvostelun toistettavuutta tutkittiin elävillä ketuilla eräăllä yksityisellä tarhalla Pohjois-Karjalassa. Ensimmäisessă kokeessa tarhan viisi työntekijảă arvosteli värin ja koon 248 hopeaketulta ja toisessa kokeessa yksi henkilő arvosteli yleisvaikutelman 2063, eri värityyppejä olevalta ketulta. Eläimet olivat arvostelun ajan häkissä. Jokainen arvostelija arvosteli eläimet kolmeen kertaan. Kaikkien ominaisuuksien pisteet muuttuivat jonkin verran arvostelun kuluessa. Arvostelijalla oli kuitenkin suurin vaikutus hopeakettujen vări- ja kokopisteisiin. Eri vărityypeillä oli eroja yleisvaikutelmasta annetuissa pisteissä.

Väri osoittautui helpommaksi arvostella kuin koko ja yleisvaikutelma. Toistuvuuskertoimet olivat 0.55 koon, 0.74 värin ja 0.57 yleisvaikutelman arvostelussa. Eri arvostelijoiden saavuttamat toistettavuudet olivat $0.51-0.59$ koon ja $0.68-0.82$ värin arvostelussa. "'Hopeatyyppien"' yleisvaikutelman arvostelu näytti olevan jonkin verran helpompaa $(r=0.57-0.59)$ kuin punertavien "'golden"' tyyppien arvostelu $(\mathrm{r}=0.50-0.55)$. 